ROCZNIK ADMINISTRACJI PUBLICZNEJ 2018 (4)

ARTYKUŁY Historia administracji / History of Administration

DOI 10.4467/24497800RAP.18.009.9224

http://www.ejournals.eu/RAP/

ISSN 2449-7800 (online), ISSN 2449-7797 (druk), s. 171-185

IRENA StawOWY-Kawka ${ }^{1}$

\title{
Prawa mniejszości narodowych i etnicznych w Albanii w okresie transformacji politycznych po $1991 \mathrm{r}$.
}

Ramowa konwencja Rady Europy o ochronie mniejszości narodowych, którą Albania podpisała 29 czerwca 1995 r., zaś ratyfikowała 3 czerwca 1999 r. ${ }^{2}$, dotyczy, jak twierdzą Albańczycy, ok. 2\% społeczności albańskiego państwa. Zdaniem badaczy z innych krajów jest to liczba bardzo zaniżona i wskaźniki są niemal dziesięciokrotnie wyższe. Na terytorium Albanii żyły narody i grupy etniczne uznawane przez państwo, do których należeli: Grecy, Macedończycy, Czarnogórcy oraz Romowie i Wołosi.

Według spisu ludności z 2011 r. ${ }^{3}$ swą narodową przynależność albańską zadeklarowało 82,58\% ankietowanych, jako Grecy określiło się 0,87\% ludności, Romowie - 0,3\%, Wołosi - 0,3\%, Macedończycy - 0,2\%, Egipcjanie - 0,12\% ${ }^{4}$ i jako Czarnogórcy - 0,01\% ${ }^{5}$. Aż 15,62\% mieszkańców Albanii nie podało swej przynależności etniczno-narodowej. Wskazywanie na występowanie innych grup narodowych - bułgarskiej, boszniackej czy serbskiej - było bezcelowe, gdyż państwo nie uznawało ich istnienia na terytorium Albanii aż do 2017 r.

${ }^{1}$ Prof. dr hab. Irena Stawowy-Kawka, Instytut Nauk Politycznych, Uniwersytet Jagielloński w Krakowie.

${ }^{2}$ Albania jest członkiem ONZ od 14 grudnia 1955 r. i ratyfikowała prawie wszystkie główne konwencje tej organizacji dotyczące ochrony praw człowieka: Powszechną Deklarację Praw Człowieka podpisała w 1948 r. (ratyfikowała ją w 1955 r.), Międzynarodową konwencję w sprawie likwidacji wszelkich form dyskryminacji rasowej podpisała w 1969 r. (ratyfikowała ją w 1994 r.), Międzynarodowy Pakt Praw Obywatelskich i Politycznych podpisała w 1966 r. (ratyfikowała go w 1991 r.), Konwencję w sprawie likwidacji wszelkich form dyskryminacji kobiet podpisała w 1989 r. (ratyfikowała ją w 1996 r.).

${ }^{3}$ Przed powszechnym spisem ludności w 2011 r. parlament albański wprowadził w życie ustawę, która głosiła, że za niewłaściwe podanie danych w czasie powszechnego spisu ludności grozi kara grzywny w wysokości 800 euro. Grecy i Macedończycy demonstrowali przeciwko wprowadzonym uregulowaniom prawnym, ale wiele osób, by uniknąć ewentualnej kary, rubryki dotyczące wyznania oraz przynależności etnicznej i narodowej wolało pozostawić puste.

${ }^{4}$ Egipcjanie to grupa Romów, która uważa, że są potomkami Egipcjan.

${ }^{5}$ Ethnic Composition of Albania 2011, 7.04.2014, http://pop-stat.mashke.org/albania-ethnic-comm2011.htm (dostęp: 10.06.2017). 
Brak odpowiedzi na temat swej identyfikacji narodowej podczas spisu ludności odnotowano w rubryce: „wolę nie odpowiadać” lub „nie ma to znaczenia"6. Z jednej strony były to osoby, które wprawdzie znały swe pochodzenie etniczno-narodowe, lecz nie chciały go podawać ze względu na brak zaufania do struktur państwa, a w warunkach fasadowej dobrowolności $^{7}$ nie chciały wypełniać tej rubryki i pozostawiły ją pustą (dotyczyło to głównie Bułgarów i Serbów), z drugiej zaś strony byli to ci, których język, kultura i tradycja tak bardzo zmieniły się pod wpływem doświadczeń historycznych, że trudno im było zdecydowanie wybrać jedną opcję. Dotyczyło to nie tylko Romów i Wołochów, którzy w zależności od warunków politycznych i ekonomicznych zmieniali swą tożsamość, ale także samych Albańczyków, którzy chętnie deklarowali się np. jako Grecy. W przypadku Macedończyków wspomniana płynność w podawaniu swej tożsamości zależała w dużej mierze od wpływów zewnętrznych (oddziaływania $\mathrm{z}$ jednej strony Macedończyków, z drugiej - Bułgarów) oraz przynależności religijnej (byli wśród nich zarówno wyznawcy islamu, jak i prawosławia).

W Albanii oficjalnie przyjmowano podział mniejszości na narodowe i kulturowe oraz etniczno-językowe ${ }^{8}$. Do tych pierwszych do 2017 r. zaliczano Greków, Macedończyków i Czarnogórców, natomiast do grup etniczno-językowych Wołochów, Romów i Egipcjan.

Podstawą niniejszego opracowania będzie próba odpowiedzi na pytanie, czy żyjące w Albanii mniejszości mają zagwarantowane prawa zgodnie ze standardami europejskimi. Czy demokracja albańska w przypadku praw dla mniejszości narodowych i etnicznych ma charakter fasadowy, złudny, a ustalenia konstytucyjne i prawo europejskie przyjęte przez Albanię nie zawsze są zgodne $\mathrm{z}$ istniejącymi realiami i warunkami politycznymi w tym kraju? Ewentualne sformułowanie negatywnej odpowiedzi na powyższe pytanie usprawiedliwia fakt, że obecny system polityczny w Albanii dopiero rozwija się w kierunku faktycznie funkcjonujących struktur demokratycznego państwa prawa. Przeprowadzane reformy, w dużym stopniu monitorowane przez UE i organizacje pozarządowe, obrały dobry kierunek. Nadal jednak wydarzenia historyczne w ogromnym stopniu wpływają na położenie mniejszości żyjących w Albanii.

Na temat mniejszości narodowych, etnicznych i religijnych w Albanii istnieje literatura naukowa, chociaż ze względu na dynamikęzagadnienia badania demograficzne muszą być prowadzone na bieżąco. Najwięcej prac opu-

${ }^{6}$ Ethnic Composition of Albania 2011...

${ }^{7}$ Wiele grup mniejszościowych skrytykowało prawo dotyczące spisu powszechnego, które nakładało grzywnę w wysokości 800 euro na każdego, kto deklarował inną grupę etniczną niż tę z Krajowego Rejestru Stanu Cywilnego wpisaną w chwili urodzenia.

${ }^{8}$ Akademia Diplomatike zhvillon seminarin me temë „Minoritetet në Shqipëri”, wykład ministra spraw zagranicznych Qirjako Qirko z dnia 15 kwietnia 2014 r. w sali konferencyjnej MSZ Akademii Dyplomatycznej. 
blikowali sami Albańczycy, jak np. L. Omari, A. Puto, V. Hysi czy R. Halili. Do prac greckich zaliczyć trzeba analizy V. Nitsiakosa i B. Kondisa ${ }^{10}$. Z opracowań macedońskich uczonych wymienić trzeba rozprawy K. Todoroskiej ${ }^{11}$ i S. Kiselinovskiego, który z I. Stawowy-Kawką (mac. Irena Stavovi-Kavka) wydał monografię o mniejszościach narodowych na Bałkanach ${ }^{12}$. Znane są publikacje w języku angielskim autorów takich jak J. Pettifer, M. Vickers czy H. Poulton ${ }^{13}$.

W Albanii nadal obowiązują niektóre rozwiązania prawne przyjęte przez władze komunistyczne, które stosowane były jeszcze w okresie międzywojennym. Dotyczy to przede wszystkim faktu uznawania mniejszości narodowych, etnicznych i religijnych wyłącznie w określonych regionach Albanii, tzw. strefach mniejszościowych, a więc nie wszędzie tam, gdzie żyją. W latach 1944-1991 stosowano różne metody mające przyspieszyć homogenizację Albańczyków wokół nacjonalistycznych wartości, sięgając np. po przesiedlania dużych grupy ludzi (głównie mniejszości narodowych, etnicznych i religijnych), osiedlanie ich wśród Albańczyków, zmienianie imion i nazwisk na albańsko brzmiące, zmienianie nazw geograficznych czy wprowadzenie zakazu posługiwania się językami mniejszości w miejscach publicznych. Sprawiło to, że mniejszości zaczęły się asymilować z ludnością miejscową. Spisy mniejszości narodowych prowadzono wówczas tylko w tzw. strefach mniejszościowych, bez możliwości podania wyznania, gdyż religia była zabroniona, a w 1967 r. Enver Hodża ateizację państwa zapisał w konstytucji.

Według oficjalnych danych albańskich (tab. 1) udział mniejszości etnicznych i narodowych w ogólnej liczbie ludności Albanii ciągle maleje. Wiąże się to nie tylko z procesami asymilacyjnymi, ale także z mniejszą liczbą urodzeń wśród ludności mniejszości, zwłaszcza Greków, w stosunku

${ }^{9}$ L. Omari, Çıёshtja e pakicave kombëtare dhe Shqipëria, Tiranë 2014; R. Halili, Macedonians in Albania - from Ethnic Group to National Minority [w:] Macedonia; Land, Region, Borderland, J. Sujecka (red.), Warszawa 2013, s. 483-505; Minoritetet në Shqipëri, A. Puto, V. Hysi (eds.), Tiranë 2003. W ramach obchodów 100 rocznicy niepodległości Albanii w 2013 r. odbyła się w Tiranie międzynarodowa konferencja naukowa pt.: „Albania i mniejszości narodowe, etniczne oraz kulturowe”.

${ }^{10}$ V. Nitsiakos, On the Border. Transborder Mobility, Ethnic Groups and Boundaries along the Albanian - Greek Frontier, Berlin 2010; The Greek Minority in Albania: A Documentary Record, 1921-1993, B. Kondis (ed.), Eleftheria Manda, Thessaloniki 1994.

${ }^{11}$ К. Тодороска, Македониите во Алнаиа (1912-1991), Скопје 2013.

${ }^{12}$ С. Киселиновски, И. Ставови-Кавка, Малиинствата на Балканот (ХХ век), Скопје 2004.

${ }^{13}$ J. Pettifer, The Greek Minority in Albania. In the Aftermath of Communism, „Conflict Studies Research Centre” 2001, no. 97, July; J. Pettifer, The Greek Minority in the Albanian Rising, "Anglo-Hellenic Review” 1997, no. 16, Autumn; M. Vickers, The Greek Minority in Albania. Current Tension, „Balkans Series” 2002, no. 10, http:// www.voltairenet.org/IMG/pdf/Greek_minority_in_Albania.pdf, (dostęp 10.06.2017); H.T. Norris, Islam in the Balkans, London 1993; H. Poulton, Minorities in Southeast Europe: Inclusion and Exclusion, London 1998. 
do Albańczyków oraz z procesami emigracyjnymi po 1991 r., gdy zostały otwarte granice.

Tab. 1. Liczba ludności mniejszości narodowych i ich procentowy udział w ogólnej liczbie ludności w Albanii w latach 1960-2011

\begin{tabular}{|c|c|c|}
\hline Rok & $\begin{array}{c}\text { Liczba ludności } \\
\text { mniejszości narodowych }\end{array}$ & $\begin{array}{c}\text { Procent ogólnej liczby } \\
\text { ludności }\end{array}$ \\
\hline 1960 & 44570 & 2,7 \\
\hline 1979 & 64816 & 2,1 \\
\hline 1989 & 54587 & 2,0 \\
\hline 2011 & 52890 & 1,9 \\
\hline
\end{tabular}

Źródło: Raport mbi Pakicat Kombetare ne Shqiperi - 2001, Burimi: Regjistrimi i Pergjithshem i Popullsise dhe i Banesave i vitit 1989, botim i Drejtorise se Statistike, Faqe 6 nga 113, https://rm.coe.int/168008a6af (dostep: 6.10.2017); Minoritetet etnike në Shqioëri, http:// open.data.al/sq/lajme/lajm/lang/sq/id/673/Minoritetet-etnike-ne-Shqiperi (dostęp: 6.10.2017).

Po 1991 r. prawodawstwo mniejszościowe w Albanii było tworzone od podstaw, nadal jednak obowiązywało prawo zgodne z zasadą, że mniejszości narodowe żyją tylko w tzw. strefach mniejszościowych. W stosunku do przyjmowania obywatelstwa albańskiego lub obcego rząd w Tiranie zastosował normę zgodną z deklaracją Ligi Narodów podpisaną przez Albanię 2 października $1921 \mathrm{r}$. Wówczas to $\mathrm{w}$ ciągu dwóch lat od wprowadzenia w życie postanowień deklaracji obywatele mogli zadeklarować, że są innej narodowości i mają obywatelstwo innego państwa, ale chcą żyć w Albanii. Grek żyjący w Albanii mógł uzyskać obywatelstwo albańskie. Sporządzony na tej podstawie Regjistri Kombëtar i Gjendjes Civile (Krajowy Rejestr Stanu Cywilnego) obowiązuje do dzisiaj i jeśli ktoś nie jest w nim zapisany jako obywatel innego kraju, nie ma podstaw do zmiany obywatelstwa albańskiego na inne. Reguluje to obecnie ustawa nr $10129 \mathrm{z}$ dnia 5 listopada 2009 r. $(\text { art. 58) })^{14}$.

Dane z Krajowego Rejestru Stanu Cywilnego dotyczące obywatelstwa były przez władze $\mathrm{w}$ Tiranie wykorzystywane do sporządzenia statystyk obejmujących pochodzenie narodowe i etniczne, które wpisywano zaraz po urodzeniu się dziecka na podstawie danych o rodzicach ${ }^{15}$. W ten sposób narodowość uzyskiwało się przez urodzenie. Jednak, jak podkreślały wła-

${ }^{14}$ Zob. treść ustawy zmienioną decyzją nr $52 \mathrm{z}$ dnia 1 grudnia 2011 r. Trybunału Konstytucyjnego Në mbështetje të neneve 78 dhe 83 pika 1 të Kushtetutës, me propozimin e Këshillit të Ministrave, zgodnie z art. 78 i 83 ust. 1 Konstytucji, na wniosek Rady Ministrów, Ligj Nr. 10/129, datë 11.05.2009, „Për Gjendjen Civile”, Ndryshuar me ligjin Nr. 6/2012, datë 2.02.2012 Nr. 130/2013, date 25.4.2013 (I përditësuar), Në mbështetje të neneve 78 dhe 83 pika 1 të Kushtetutës, me propozimin e Këshillit të Ministrave, http://www.vendime.al/wp-content/uploads/2015/07/LIGJ-Nr.-10-129_ dat\%C3\%AB-11.5.2009-P\%C3\%8BR-GJENDJEN-CIVILE.pdf (dostęp: 6.10.2017).

${ }^{15}$ Ibidem, rozdział II, art. 6; zob także Minoritetet etnike në Shqioëri... 
dze w Tiranie, dla dobra obywateli zmieniono zasadę z 1921 r. i pozwolono na swobodne określanie swej przynależności narodowej, etnicznej i religijnej w czasie spisu ludności w $2011 \mathrm{r}^{16}$, w maju tego roku zniesiono bowiem praktykę obowiązkowej rejestracji w aktach urodzenia pochodzenia narodowego i etnicznego dla osób należących do greckiej i macedońskiej mniejszości żyjących w tzw. strefach mniejszościowych, a przyjęto model dobrowolnej deklaracji. Nie uczyniono jednak tego wobec wszystkich obywateli Albanii. Na terytorium kraju poza strefami mniejszościowymi obowiązywał nadal wpis z Krajowego Rejestru Stanu Cywilnego. Rada Europy w Rezolucji CM/Res CMN (2014) o wdrażaniu przez Albanię Ramowej Konwencji stwierdziła, że przepis ten narusza prawa innych mniejszości i je dyskryminacje $\mathrm{e}^{17}$.

Obowiązująca obecnie w Albanii konstytucja została przyjęta przez parlament 21 października 1998 r. Zastąpiła ona ustawę zasadniczą uchwaloną w 1991 r. i zagwarantowała obywatelom wolność słowa i wyznania, równość wobec prawa bez względu na wiek, płeć, przynależność etniczną, religię, zapewniła także mniejszościom narodowym pielęgnowanie własnych tradycji i języka. Wiązało się to z dobrosąsiedzką polityką i dążeniem Albanii do integracji z EU. O podstawowych prawach i wolnościach stanowią w konstytucji rozdział II „Wolności i prawa osobiste” (art. 21-44), rozdział III „Wolności i prawa polityczne” (art. 45-48) oraz rozdział IV „Wolności i prawa ekonomiczne, społeczne i kulturalne" (art. 49-58). Udział Albanii w międzynarodowych organizacjach takich jak OBWE czy Rada Europy oraz podpisanie licznych konwencji dotyczących praw człowieka doprowadziły do wypracowania norm ${ }^{18}$ dotyczących przestrzegania i szanowania praw mniejszości. Były to pierwsze kroki, które w potem korygowano i stopniowo wprowadzano w życie.

Konstytucja Albanii w części I pt. „Zasady ogólne” w art. 3 stanowi: „Niepodległość państwa i nienaruszalność jego terytorium, godność człowieka, jego prawa i wolności, sprawiedliwość społeczna, porządek konstytucyjny, pluralizm, tożsamość narodowa i dziedzictwo narodowe, współistnienie religii, jak też współżycie i wzajemne zrozumienie Albańczyków z mniejszościami stanowią podstawę państwa, którego obowiązkiem jest ich poszanowanie i obrona"19.

Artykuł $20 \$ 1$ statuuje, że „Osoby należące do mniejszości narodowych wykonują swoje prawa i wolności pozostając w pełnej równości wobec prawa”. Natomiast w art. $20 \$ 2$ stwierdza się: „Osoby należące do mniejszości

${ }^{16}$ Ibidem.

${ }^{17}$ Resolution CM/Res CMN(2014)1 on the implementation of the Framework Convention for the Protection of National Minorities by Albania, https://wcd.coe.int/ViewDoc.jsp?id=2161315 (dostęp: 10.06.2015).

${ }^{18}$ Zob. R. Predpełski, Religie i wyznania w Albanii, http://albania.republika.pl/Religie\%20w\%20Albanii.pdf (dostęp: 10.06.2017).

${ }^{19}$ Konstytucja Albanii z 1998 roku, tłum. D. Horodyska, E. Lloha, Warszawa 2001, http://libr.sejm.gov.pl/tek01/txt/konst/albania98.html (dostęp: 10.06. 2017). 
narodowych wykonują swoje prawa i wolności, pozostając w pełnej równości wobec prawa. Osoby te posiadają prawo do swobodnego wyrażania, bez poddawania ich zakazom czy obowiązkom, swojej przynależności etnicznej, kulturalnej, religijnej i językowej. Przysługuje im prawo do ochrony i rozwoju, do uczenia się i zdobywania wykształcenia w ich języku ojczystym, jak też do zrzeszania się w organizacjach i stowarzyszeniach chroniących ich interesy i tożsamość" 20 .

Kolejnym aktem chroniącym prawa mniejszości była ustawa z 2002 r., nr 10221 o ochronie przed dyskryminacją. Gwarantowała równość prawa wobec wszystkich obywateli, ustalała zasady, reguły i środki walki z dyskryminacją, prawo do nauki, dostęp do towarów i usług oraz do zatrudnienia ${ }^{21}$.

W Albanii działa Rzecznik Praw Obywatelskich, który składa przed paramentem coroczne sprawozdanie o przestrzeganiu prawa lub jego przekraczaniu przez władze albańskie wobec obywateli, w tym grup etniczno-językowych, narodowych i religijnych na terenie Albanii. Rzecznik, chociaż nie ma uprawnień egzekucyjnych, monitoruje sytuację i traktowanie mniejszości narodowych, etnicznych i religijnych w kraju, a instytucje publiczne w niektórych przypadkach mogą wszcząć dochodzenie, gdy ofiary nie są w stanie same wystąpić i wszcząć procedury dotyczącej poprawy ich sytuacji. Obywatele mogą składać skargi na policję w związku $\mathrm{z}$ niewłaściwym postępowaniem ${ }^{22}$. W Albanii istnieją zatem prawa i systemy, które umożliwiają dochodzenie roszczeń w związku z dyskryminacją i szykanami. Jednak często, zwłaszcza wśród Romów i Egipcjan, występuje brak znajomości prawa lub spotkać się można z niechęcią poszczególnych osób do poszukiwania ochrony.

Definicję mniejszości narodowej w Albanii podała A. Azizaj, która twierdziła, że jest to grupa, która spełnia następujące warunki:

- zamieszkuje terytorium państwa jako jego obywatele,

- utrzymuje silne związki z krajem, w którym mieszka,

- posiada swe specyficzne cechy etniczne, kulturowe, religijne lub językowe,

- jest mniej liczna niż reszta populacji tego państwa lub jednego z regionów, ale odpowiednio reprezentatywna,

${ }^{20}$ Ibidem.

${ }^{21}$ Republika e Shqipërisë, Avokatii i Popullit, Raport $i$ Veçantë, Raport i posaçëm $i$ veprimtarisë së Avokatit të Popullit për punësimin e Personave me Aftësi të Kufizuar (PAK), në institucionet e pushtetit qendror e atij lokal, Prill 2013, http://www. parlament.al/web/pub/2013_raporti_per_ligjin_e_nxitjes_se_punesimit_te_pak_ copy_1_15423_1.pdf (dostęp:10.06.2017).

${ }^{22}$ Home Office, Country Policy and Information, Note Albania: Ethnic minority groups, Version 3.0, May 2017, http://www.refworld.org/pdfid/591d66744.pdf (dostęp:10.06.2017), s. 5. 
- ma wolę, by zachować swą kulturę, tradycję, religię i język ${ }^{23}$.

Autorka zaznacza, że istnieją ogromne trudności z określeniem istoty mniejszości narodowej i przyjęciem jednej definicji obowiązującej wszystkie kraje, które podpisały Konwencję Rady Europy. Na ten problem zwraca też uwagę L. Omari ${ }^{24}$.

Niemniej jednak sprawa nie ograniczała się tylko do kwestii definicji - większe znaczenie ma fakt, że istnienie nawet wielu grup etnicznych, narodowych, religijnych jako jednostek kulturowych było jawnie ignorowane przez państwa-sygnatariuszy Konwencji. W ten sposób powstało to, co krytycy nazwali paradoksem narzuconego przez państwo „rozpoznania” grup mniejszościowych. W ten sposób każde państwo ma wolną wolę w ocenianiu i decydowaniu, które mniejszości obejmuje Konwencja Rady Europy.

Definicja stosowana w Albanii, przyjęta jeszcze w okresie komunistycznym, ograniczała się do terytoriów zamieszkałych przez mniejszości w zwartej grupie. Mieszane miejscowości spoza wyznaczonego obszaru, nawet tam, gdzie w zdecydowanej większości przeważały mniejszości, nie były definiowane jako strefy mniejszościowe i ludność tam zamieszkała nie miała praw należnych mniejszościom. Dotyczyło to także dużych miast albańskich. Dlatego Albania ciągle z niedoszacowaniem podaje liczbę swych mniejszości etnicznych, narodowych i religijnych. Bardzo ważną rolę pełnią w takiej sytuacji badania terenowe - etnograficzne. Prowadzący je w latach 1992 i 1995 T.J. Winnifrith ${ }^{25}$ opisał ogromne trudności, jakie musiał pokonać w południowo-wschodniej Albanii, gdzie żyje największa liczba mniejszości narodowych i etnicznych. Jako kryterium przynależności do odpowiedniej grupy Winnifrith posłużył się językiem, jakim mieszkańcy mówią w rodzinnym domu. Jego badania dotyczyły Wołochów.

Aby dostosować prawo do standardów europejskich, albański rząd od września 2013 r. prowadził prace nad wdrożeniem reformy administracyjno-terytorialnej w celu reorganizacji jednostek samorządu terytorialnego. Parlament albański 31 lipca 2014 r. dokonał nowelizacji ustawy nr 8562/2000, przeprowadzając reformę administracyjno-terytorialną przez wprowadzenie w życie ustawy 115/2014. By wdrażać zasady zrównoważonego rozwoju w administracji lokalnej i centralnej, zrezygnowano $z$ rozdrobnionego podziału administracyjnego i terytorialnego, który opierał się głównie na tradycji organizacji państwowej rządów komunistycznych (obsługiwał np. spółdzielnie rolnicze) i nie odzwierciedlał tempa wzrostu gospodarczego, rozwoju społecznego, demograficznego i infrastruktury.

${ }^{23}$ A. Azizaj, Çështja e minoriteteve në plnin ndërkombëtar, për mbrojtjen e diplomës, Vlorë 2009, s. 10.

${ }^{24}$ L. Omari, Çıёshtja e pakicave..., s. 245.

${ }^{25}$ T.J. Winnifrith, Southern Albania, Northern Epirus: Survey of a Disputed Ethnological Boundary, http://www.farsarotul.org/nl17_1.htm (dostęp: 10.06.2017). 
Przez decentralizację ustawa ta likwidowała rozdrobniony podział administracyjny.

Ustawa weszła w życie 16 września 2014 r., wprowadzając znaczące zmiany dotyczące podziału administracyjno-terytorialnego. $Z$ dotychczas istniejących od 2000 r. 309 gmin zostało tylko 61, które stały się podstawowym ogniwem administracyjnym. Jednostkami wyższego rzędu pozostało 12 okręgów (województw). Kontynuacją reformy była ustawa 44/2015, uchwalona dnia 30 kwietnia 2015 r., która weszła w życie 28 maja 2015 r. i wprowadziła nowy kodeks postępowania administracyjnego oraz poprawki do ustawy o organizacji i funkcjonowaniu samorządu lokalnego. Głównym celem tej reformy było zbliżenie do aquis communautaire i zastosowanie praktyk przyjętych $\mathrm{w}$ UE. Jednym $\mathrm{z}$ podstawowych zadań stworzenia nowych struktur administracyjnych, w których gmina stała się kluczową jednostką administracyjno-terytorialną, stanowiącą drugi poziom samorządu terytorialnego, była poprawa efektywności zarządzania na szczeblu gminy, czyli na poziomie lokalnym. Zgodnie z definicją podaną przez ustawodawcę gmina to jednostka administracyjna i terytorialna złożona $\mathrm{z}$ miast i wsi, mająca wspólną historię, tradycję, związki gospodarcze i społeczne $e^{26}$.

Funkcjonowanie ustawy stało się możliwe po wyborach samorządowych w Albanii, które odbyły się 21 czerwca 2015 r. Dla wsparcia reformy powstał program STAR 2, który zapewniał pomoc międzynarodową: Unii Europejskiej ${ }^{27}$, rządu Szwecji za pośrednictwem Agencji Rozwoju Międzynarodowego, rządu Włoch poprzez Włoską Agencję Rozwoju, rządu Szwajcarii poprzez Szwajcarską Agencję ds. Rozwoju i Współpracy, USA za pośrednictwem Amerykańskiej Agencji ds. Rozwoju Międzynarodowego ${ }^{28}$. Zaangażowanie programu STAR $2 \mathrm{w}$ reformę miało na celu zwiększenie przejrzystości instytucji publicznych (walka z korupcją), demokratyzację podejmowania decyzji przez obywateli na szczeblu podstawowym, wzrost zaangażowania obywateli $\mathrm{w}$ proces transformacji i modernizacji świadczenia usług ${ }^{29}$. Ustawa ta $\mathrm{w}$ regionach, które zamieszkiwały mniejszości, była bardzo ważna, dlatego w wyborach samorządowych brały one czynny udział. Jak podano w raporcie OBWE, znacznie wzrosła aktywność i zaangażowanie Romów i Egipcjan w kampanię przedwyborczą, chociaż ze

${ }^{26}$ Ligj Nr. 115/2014 Për ndarjen administrativo-territoriale të njësive të qeverisjes vendore në Republikën e Shqipërisë, http://himara.gov.al/ligj-nr-1152014-per-ndarjen-administrativo-territoriale-te-njesive-te-qeverisjes-vendore-ne-republiken-e-shqiperise/ (dostęp: 6.10.2017).

${ }^{27} \mathrm{~W}$ ramach współpracy między UE i Albanią w dziedzinie samorządu lokalnego delegacja UE 20 grudnia 2016 r. podpisała umowę finansową o wartości 3,5 mln euro na wsparcie reformy.

${ }^{28}$ Reforma Territoriale - KRYESORE, http://www.reformaterritoriale.al/ (dostęp: 6.10.2017).

${ }^{29}$ Ibidem. 
względu na ubóstwo tej mniejszości etniczno-językowej nadal zdarzały się praktyki kupowania głosów za bony paliwowe lub pieniądze ${ }^{30}$. Zwycięstwo odniosła partia polityczna Macedoński Sojusz na rzecz Integracji Europejskiej (тас. Македонска алијанса за европска интеграција (MAEI), alb. Partia Aleanca e Maqedonasve për Integrim Europian (AMIE)), a Macedończyk Edmond Temelko został burmistrzem gminy Pustec. Natomiast

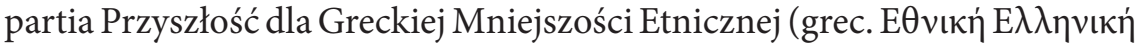

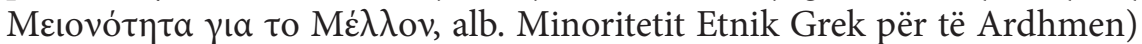
z Leonidhą Hristo na czele wygrała wybory w gminie Finiq. Przedstawiciel greckiej partii został zastępcą burmistrza w gminie Saranda (lub Sarandë).

Nowy podział administracyjny z 2014 i 2015 r. spowodował, że spośród 61 gmin (alb. bashki) 58 zostało uznawanych za albańskie, 2 - za greckie i 1 - za macedońską. W ten sposób tzw. strefy mniejszościowe przypisano odpowiednim gminom i tam zagwarantowano jej mieszkańcom prawa mniejszościowe.

28 września 2017 r. grecki minister spraw zagranicznych Nikos Kotzias w wywiadzie telewizyjnym stwierdził: „Wyjaśniłem na forum ONZ i wiele osób ten problem zrozumiało, że sprzeczne jest [z oczywistymi faktami I.S.K.], iż mniejszość uznawana jest tylko (...) w dwóch obszarach znanych jako takie, a jeśli opuścisz swoją wioskę, aby udać się do Tirany, nie jesteś już mniejszością. Mniejszość powinna być uznawana na całym terytorium Albanii i wszędzie tam, gdzie się znajduje"31.

Parlament Europejski w 2016 r. zwrócił uwagę na potrzebę respektowania w Albanii praw wszystkich mniejszości narodowych i wdrożenia odpowiedniego prawodawstwa oraz wydał zalecenie o uznaniu praw mniejszości bułgarskiej w regionach Prespa (alb. Prespës), Golloborda (mac. Golo Brdo) i Gorë (mac. Gora), tak, by mogły być one realizowane w praktyce ${ }^{32}$. Aby dostosować prawo w Albanii do założeń ramowej konwencji Rady Europy o ochronie mniejszości narodowych i wytycznych Parlamentu Europejskiego, 13 października 2017 r. uchwalono ustawę o ochronie mniejszości narodowych w Republice Albanii ${ }^{33}$. Według art. $3 \$ 1$ tej ustawy: „Mniejszość narodowa to grupa obywateli Albanii zamieszkująca Republikę Albanii mająca wczesne [od urodzenia - I.S.K.] i trwałe relacje

${ }^{30}$ Home Office, Country Policy and Information Note, Albania: Ethnic Minority Groups, version 3.0, May 2017, http://www.refworld.org/pdfid/591d66744.pdf (dostęp: 25.11.2017), s. 19 i 20.

${ }^{31}$ N. Kotzias, Minoriteti grek në Shqipëri të njihet kudo, 28 Shtator 2017, http://klankosova.tv/kotzias-minoriteti-grek-ne-shqiperi-te-njihet-kudo/ (dostęp: 25.11.2017).

${ }^{32}$ Commission Report on Albania (2016/2312(INI)), Report, 3 February 2917 (raport Komisji Spraw Zagranicznych Parlamentu Europejskiego), http://www. europarl.europa.eu/sides/getDoc.do?pubRef=-//EP//TEXT+REPORT+A8-2017-0023+0+DOC+XML+V0//EN (dostęp:10.06.2017).

${ }^{33}$ Ligj Nr. 96/2017, Për mbrojt jen pakicave kombëtare në Republikën e Shqipërisë,http://www.qbz.gov.al/Botime/Akteindividuale/Janar\%202017/Fletore\%20196/ Ligj\%20nr.\%20962017,\%20date\%2013.10.2017.pdf (dostęp: 27.11.2017). 
z państwem albańskim, wykazująca się specyficznymi cechami kulturowymi, etnicznymi, religijnymi lub tradycją i która jest gotowa do wyrażania, utrzymywania i rozwijania swej odmiennej tożsamości kulturowej, etnicznej, językowej, religijnej lub tradycji” ${ }^{34}$.

$\mathrm{W}$ tym samym art. $3 \$ 2$ ustawa zapisano, że na terytorium Albanii, żyją mniejszości narodowe: grecka, macedońska, wołoska, romska, egipska, czarnogórska, boszniacka, serbska i bułgarska. W ten sposób rozszerzono liczbę mniejszości żyjących w tym państwie przez dodanie mniejszości bułgarskiej, boszniackiej i serbskiej. Nadto ustawa znosi podział na mniejszości narodowe i kulturowe oraz etniczno-językowe. W myśl tego aktu do mniejszości narodowych należą także Wołosi, Romowie i Egipcjanie, co daje im takie same prawa jak Grekom, Macedończykom, Bułgarom, Serbom i Czarnogórcom.

Artykuł 6 ustawy przyznaje mniejszościom prawo do swobodnej samoidentyfikacji narodowej, etnicznej, językowej i religijnej, jednocześnie w art. 8 zapisano zakaz dyskryminacji osób należących do mniejszości, a także stworzono możliwość swobodnego zrzeszania się i reprezentowania swych interesów na różnych szczeblach w organach przedstawicielskich, tj. w życiu publicznym, kulturalnym, społecznym i gospodarczym.

Prawodawca $\mathrm{w}$ art. 12 ustawy przyznaje mniejszościom narodowym, etnicznym i religijnym na całym terytorium Albanii prawo do zachowania i rozwoju języka, kultury, religii i dziedzictwa kulturowego, świętowania wydarzeń związanych z promocją tożsamości oraz wprowadza zakaz polityki i praktyk mających na celu asymilację mniejszości.

Mniejszości mają prawo do nauki w swoim języku wszędzie tam, gdzie istnieje taka potrzeba (kryteria zapotrzebowania na naukę ustalają jednostki samorządu terytorialnego, zgodę wydaje Rada Ministrów na wniosek ministrów odpowiedzialnych za edukację i samorząd lokalny). Obowiązek zapewnienia odpowiednich środków finansowych w dziedzinie edukacji mniejszości narodowych, jak druk podręczników szkolnych, doskonalenie i szkolenie zawodowe nauczycieli, spoczywa na Radzie Ministrów oraz ministrze edukacji. Nadto mniejszości narodowe mają prawo do otwierania szkół i zarządzania nimi oraz powoływania instytucji kształcenia zawodowego, ale tylko wówczas, gdy zostały spełnione wszystkie warunki przewidziane ustawowo w dziedzinie edukacji. Szkoła prywatna nie może wprowadzać regulacji zawężających zakres nauczania języka albańskiego ${ }^{35}$.

Ustawa mniejszościowa z 13 października 2017 r. w art. 14 daje gwarancję wolności słowa, sumienia i prawa do informacji dla mniejszości narodowych żyjących w Albanii przez prawo do posiadania własnych mediów, możliwość korzystania $\mathrm{z}$ usług radiowych i audiowizualnych, nadawanie licencji na usługi radiowo-telewizyjne, które emitowane miały być w języ-

\footnotetext{
${ }^{34}$ Ibidem.

${ }^{35}$ Art. 13 ustawy z 2017 r.
} 
kach mniejszości (w tym programy informacyjne i kulturalne). Publiczne radio i telewizja mają emitować programy informacyjne i kulturalne $\mathrm{w}$ językach mniejszości. Uregulowania te były bardzo ważne, albowiem po raz pierwszy po 1991 r. ustawodawca uznał, że poza strefami mniejszościowymi żyją mniejszości narodowe, które zostały objęte regulacją prawną.

Ustawodawca inaczej odniósł się do zapisów dotyczących używania języków mniejszości narodowych żyjących w Albanii. Bardzo ważne z punktu widzenia przestrzegania praw mniejszości w Albanii jest respektowanie Europejskiej Karty Języków Regionalnych lub Mniejszościowych. W pkt 20 Raportu Komisji Spraw Zagranicznych Parlamentu Europejskiego z 2016 r. wezwano Albanię do ratyfikowania Karty Języków ${ }^{36}$. Ustawa z 13 października 2017 r. stanowi w art. 15, iż w gminach, w których liczba członków danej mniejszości przekracza 20\%, w miarę możliwości samorządu lokalnego będą tworzone warunki do posługiwania się językiem tej mniejszości $\mathrm{w}$ organach administracyjnych. W gminach tych oprócz nazw albańskich, powinny funkcjonować nazwy miejscowe $\mathrm{w}$ języku danej mniejszości. $\mathrm{W}$ jednostkach samorządu regionalnego, w których osoby należące do mniejszości narodowych stanowią ponad $20 \%$ całkowitej populacji, ludność należąca do mniejszości ma prawo otrzymania informacji w języku mniejszości na temat procesu wyborczego, co reguluje Centralna Komisja Wyborcza. Nadto każda osoba aresztowana ma prawo zostać poinformowania w języku mniejszości o charakterze i przyczynie takiego aresztowania ${ }^{37}$.

W ten sposób ustawodawca ograniczył możliwość używania języka mniejszości narodowych do trzech gmin (dwóch greckich i jednej macedońskiej) w administracji publicznej, sądach i podczas wyborów oraz dwujęzyczność do jednostek samorządowych (gmin), na których terytorium żyje ponad $20 \%$ danej mniejszości w stosunku do ogólnej liczby jej mieszkańców. W konsekwencji nowej ustawy zostały zniesione działające od $1921 \mathrm{r}$. tzw. strefy mniejszościowe, a w praktyce zmieniono je na gminy mniejszościowe o szczególnych uprawnieniach dotyczących używania języków mniejszości.

W celu zapewnienia ochrony i poszanowania praw i interesów mniejszości narodowych powołano pod przewodnictwem premiera Komitet ds. Mniejszości Narodowych. Do kompetencji tego organu należą: opiniowanie i zalecania procesu legislacyjnego i działań na rzecz mniejszości narodowych, przygotowanie i przedkładanie okresowych sprawozdań w parlamencie na temat działalności Komitetu, współpraca i koordynacja działań instytucji samorządowych szczebla centralnego i lokalnego, raportowanie i monitorowanie wdrażania ram prawnych, wzmocnienie dialogu między Albańczykami i mniejszościami narodowymi, przygotowanie sprawozdania z realizacji Ramowej konwencji Rady Europy o ochronie mniejszości

\footnotetext{
${ }^{36}$ Commission Report on Albania (2016/2312(INI)), pkt 20.

${ }^{37}$ LIGJ, Nr. 96/2017.
} 
narodowych, wydawanie opinii na temat umów międzynarodowych, by te były zgodne z prawami i wolnościami mniejszości narodowych ${ }^{38}$.

Każda mniejszość ma prawo do posiadania jednego członka w składzie tego Komitetu, który powoływany jest na czteroletnią kadencję przez premiera. W celu sprawnego wdrażania ustawy i wspierania inicjatyw mniejszości narodowych powołano odpowiedni fundusz stworzony z budżetu państwa i zarządzany przez Komitet Mniejszości. W ten sposób realizacja praw i swobód mniejszościowych poza trzema gminami mniejszościowymi zależy w dużym stopniu od działań Komitetu Mniejszości, który działał pod przewodnictwem premiera.

Wprowadzenie w życie omówionej wyżej ustawy to ważne zadanie dla obecnych władz albańskich w procesie demokratyzacji życia publicznego Albanii. Jego realizacja zależeć będzie od wielu czynników, przede wszystkim od decyzji i polityki samego premiera, ale ustawa rezerwuje też wiele kompetencji dla odpowiednich ministrów odpowiedzialnych za resorty szkolnictwa, kultury i samorządu lokalnego.

Mimo ważnych decyzji i zmian krytycznie do ustawy odnieśli się nie tylko Grecy, jak i Macedończycy, ale także Wołosi, trzy najliczniejsze mniejszości narodowe żyjące w Albanii. Vangjel Dulè, przedstawiciel mniejszości greckiej z Unii na rzecz Praw Człowieka (alb. Partia Bashkimi për të Drejtat

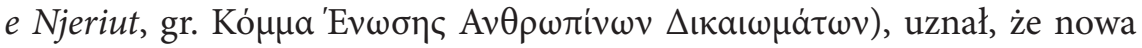
ustawa jest krokiem wstecz. Nie respektuje ona bowiem ani praw mniejszości, ani zaleceń Rady Europy. Brak było w albańskim parlamencie mniejszości narodowych, które mogłyby zabiegać o swe prawa i intersy. Według tego polityka, który do 2015 r. współpracował z Socjalistyczną Partią Albanii, będąc głównym współkoalicjantem i zarazem wiceprzewodniczącym parlamentu ${ }^{39}$, w ustawie o mniejszościach należało zastosować model chorwacki czy czarnogórski, które respektowały uczestnictwo polityczne mniejszości w parlamencie. Nadto podkreślił, że nadal mniejszości nie mają prawa do swobodnego określania swej narodowości, a stanowi o tym wypis z Krajowego Rejestru Stanu Cywilnego ${ }^{40}$.

Natomiast oficjalne uznanie mniejszości bułgarskiej w Albanii wywołało krytykę Macedończyków. Lider macedońskiej partii Ilinden (Илинден) Nikola Gjurgjaj oraz aktywiści z Macedońskiego Sojuszu na rzecz Integracji Europejskiej (mac. MAEI Македонска алијанса за европска интеграција, alb. Aleanca Maqedonase për Integrimin Europian) ostro zaprotestowali wobec uznania mniejszości bułgarskiej w Albanii. Gjurgjaj twierdził: „Władze albańskie zdają sobie sprawę z tego, że są w błędzie, ale

${ }^{38}$ Ibidem, art. 19.

${ }^{39}$ Vangjel Dulè ze swej funkcji zrezygnował w 2015 r. po wprowadzeniu w życie reformy administracyjnej, która region Himarë, w którym żyją Grecy, pozostawiła poza gminami greckimi.

${ }^{40}$ Vangjel Dule kundër ligjit të minoriteteve, https://www.vizionplus.tv/vangjel-dule-kunder-ligjit-te-minoriteteve/ (dostęp: 27.11. 2017). 
uległy bułgarskim groźbom, by w Sofii nie zawetowano rozpoczęcia rozmów o członkostwie w UE. W Albanii, według wszystkich spisów ludności, nie było mniejszości bułagrskiej (...) to jest (...) wypaczenie historii i prawdy" ${ }^{41}$. Podkreślał, że żyjący w Golloborda (mac. Golo Brdo) i Gorë (mac. Gora) Macedończycy nie mają żadnych praw - ani do szkolnictwa w języku ojczystym, ani też do używania swej mowy w miejscach publicznych i administracji ${ }^{42}$. Gjurgjaj wystąpił do władz w Tiranie o wystawianie oficjalnych dokumentów w języku macedońskim obywatelom albańskim narodowości macedońskiej. Zastrzeżenia Greków i Macedończyków wpierali Wołosi, którzy chcieliby zmiany swej konstytucyjnej nazwy z Wołochów na Arumunów. Projekt takich zmian pojawił się w parlamencie podczas dyskusji nad ustawą.

Uchwalenie ustawy o ochronie mniejszości narodowych, która uznaje bułgarską mniejszość w Albanii, z zadowoleniem przyjęto w Sofii, a sam premier Bojko Borysow pogratulował albańskiemu premierowi Ediemu Ramie przyjęcia takich rozwiązań.

Dzisiaj możemy jedynie zastanawiać się, jak będzie wyglądała implementacja wprowadzonych w 2017 r. przepisów prawnych dotyczących mniejszości narodowych. Należy się spodziewać, że prounijne władze w Tiranie premiera Ediego Ramy zrealizują postawione przed Albanią zadania. Szef delegacji Zgromadzenia Rady Parlamentarnej Europy Paolo Corsini podkreślił: „Nadszedł czas, by Albania podjęła działania na rzecz autentycznej demokracji opartej na prymacie prawa"43. Tirana, czyniąca stałe postępy w kluczowych dziedzinach dla rozpoczęcia negocjacji akcesyjnych, zapewne będzie zmieniała swe podejście do poszanowania praw mniejszości narodowych. Stan obecny przedstawia nienajlepszy obraz regulacji w sprawie ochrony mniejszości, które w dużej mierze mają fasadowy charakter. Wprawdzie przyjęte zostały zobowiązania międzynarodowej Konwencji Rady Europy o Ochronie Praw Człowieka i Podstawowych Wolności oraz ratyfikowana większość międzynarodowych konwencji praw człowieka, to jednak kompleksowe przepisy dotyczące mniejszości nie zostały wprowadzone w życie. Prawem mniejszościowym zostały objęte przede wszystkim osoby w tzw. strefach mniejszościowych (od 2017 r. gminach mniejszościowych). Czy zgodnie z ustawą z 13 października 2017 r. Albania będzie poszerzała te uprawnienia na obywateli spoza gmin mniejszościowych, po-

${ }^{41}$ Албански парламент усвои законот за малцинствата, 14 октомври 2017, „МИА”, http://www.mia.mk/mk/Inside/RenderSingleNews/288/133907943\# (dostęp: 27.11.2017).

${ }^{42}$ Nikola Gjurgjaj Speaks on the Level of Rights of Ethnic Macedonians in Albania, 24 February 2017, „MIA”, http://www.mia.mk/Mobile/en/Home/RenderSingleNews/324? newsID=133584752 (dostęp: 27.11.2017).

${ }^{43}$ OBWE jest zadowolona $z$ wyborów $w$ Albanii $i$ wzywa rzad do reform, które umożliwia państwu członkostwo w UE, 27.06.2017, https://pl.sputniknews.com/ polityka/201706275757795-Albania-wybory-UE-OBWE/ (dostęp: 27.11.2017). 
każe przyszłość. Wolność gromadzenia się i stowarzyszania się w Albanii są na ogół przestrzegane, brak jednak odpowiednich procedur zbierania i przetwarzania danych statystycznych dotyczących liczby i zamieszkania mniejszości narodowych tak, aby były one wiarygodne.

\section{Bibliografia}

Албански парламент усвои законот за малиинствата, 14 октомври 2017, „МИА”, http://www.mia.mk/mk/Inside/RenderSingleNews/288/133907943\#.

Azizaj A., Çështja e minoriteteve në plnin ndërkombëtar, për mbrojtjen e diplomës, Vlorë 2009.

Commission Report on Albania (2016/2312(INI)), Report, 3 February 2917 (raport Komisji Spraw Zagranicznych Parlamentu Europejskiego), http://www. europarl.europa.eu/sides/getDoc.do?pubRef=-//EP//TEXT+REPORT+A8-2017-0023+0+DOC+XML+V0//EN.

Ethnic Composition of Albania 2011, 7.04.2014, http://pop-stat.mashke.org/albania-ethnic-comm2011.htm.

Halili R.R., Macedonians in Albania - from Ethnic Group to National Minority [w:] Macedonia; Land, Region, Borderland, J. Sujecka (red.), Warszawa 2013, s. 483-505.

Home Office, Country Policy and Information Note, Albania: Ethnic Minority Groups, version 3.0, May 2017, http://www.refworld.org/pdfid/591d66744.pdf.

Киселиновски С., Ставови-Кавка И., Малцинствата на Балканот (ХХ век), Скопје 2004.

Kotzias N., Minoriteti grek në Shqipëri të njihet kudo, 28 Shtator 2017, http://klankosova.tv/kotzias-minoriteti-grek-ne-shqiperi-te-njihet-kudo/.

Minoritetet në Shqipëri, A. Puto, V. Hysi (ed.), Tiranë 2003.

Nikola Gjurgjaj Speaks on the Level of Rights of Ethnic Macedonians in Albania, 24 February 2017, „MIA”, http://www.mia.mk/Mobile/en/Home/RenderSingleNews/324? newsID=133584752.

Nitsiakos V., On the Border. Transborder Mobility, Ethnic Groups and Boundaries along the Albanian - Greek Frontier, Berlin 2010.

Norris H.T., Islam in the Balkans, London 1993.

OBWE jest zadowolona $z$ wyborów w Albanii $i$ wzywa rzad do reform, które umożliwiq państwu członkostwo w UE, 27.06.2017, https://pl.sputniknews.com/polityka/201706275757795-Albania-wybory-UE-OBWE/.

Omari L., Çıёshtja e pakicave kombëtare dhe Shqipëria, Tiranë 2014.

Pettifer J., The Greek Minority in the Albanian Rising, "Anglo-Hellenic Review” 1997, no. 16, Autumn.

Pettifer J., The Greek Minority in Albania. In the Aftermath of Communism, „Conflict Studies Research Centre" 2001, no. 97, July.

Poulton H., Minorities in Southeast Europe: Inclusion and Exclusion, London 1998.

Predpełski R., Religie i wyznania w Albanii, http://albania.republika.pl/Religie\%20 w\%20Albanii.pdf. 
Republika e Shqipërisë, Avokatii i Popullit, Raport $i$ Veçantë, Raport i posaçëm i veprimtarisë së Avokatit të Popullit për punësimin e Personave me Aftësi të Kufizuar (PAK), në institucionet e pushtetit qendror e atij lokal, Prill 2013, http://www. parlament.al/web/pub/2013_raporti_per_ligjin_e_nxitjes_se_punesimit_te_ pak_copy_1_15423_1.pdf.

The Greek Minority in Albania: A Documentary Record, 1921-1993, B. Kondis (ed.), Eleftheria Manda, Thessaloniki 1994.

Тодороска К., Македониите во Алнаиа (1912-1991), Скопје 2013.

Vickers M., The Greek Minority in Albania. Current Tension, „Balkans Series” 2002, no. 10, http://www.voltairenet.org/IMG/pdf/Greek_minority_in_Albania.pdf.

Vangjel Dule kundër ligjit të minoriteteve, https://www.vizionplus.tv/vangjel-dulekunder-ligjit-te-minoriteteve/.

Winnifrith T.J., Southern Albania, Northern Epirus: Survey of a Disputed Ethnological Boundary, http://www.farsarotul.org/nl17_1.htm.

\section{Akty prawne}

Konstytucja Albanii z 1998 roku, tłum. D. Horodyska, E. Lloha, Warszawa 2001, http://libr.sejm.gov.pl/tek01/txt/konst/albania98.html.

Ligj Nr. 10/129, datë 11.05.2009, „Për Gjendjen Civile”, Ndryshuar me ligjin Nr. 6/2012, datë 2.02.2012 Nr. 130/2013, date 25.4.2013 (I përditësuar), Në mbështetje të neneve 78 dhe 83 pika 1 të Kushtetutës, me propozimin e Këshillit të Ministrave, http://www.vendime.al/wp-content/uploads/2015/07/LIGJ-Nr.-10-129-dat\%C3\%AB-11.5.2009-P\%C3\%8BR-GJENDJEN-CIVILE.pdf.

Ligj Nr. 115/2014 Për ndarjen administrativo-territoriale të njësive të qeverisjes vendore në Republikën e Shqipërisë, http://himara.gov.al/ligj-nr-1152014-per-ndarjen-administrativo-territoriale-te-njesive-te-qeverisjes-vendore-ne-republiken-e-shqiperise/.

Ligj Nr. 96/2017, Për mbrojt jen pakicave kombëtare në Republikën e Shqipërisë, http://www.qbz.gov.al/Botime/Akteindividuale/Janar\%202017/Fletore\%20 196/Ligj\%20nr.\%20962017,\%20date\%2013.10.2017.pdf.

Resolution CM/Res CMN(2014)1 on the implementation of the Framework Convention for the Protection of National Minorities by Albania, https://wcd.coe. int/ViewDoc.jsp?id=2161315.

Streszczenie

Tirana, czyniąca stałe postępy w obszarach kluczowych dla rozpoczęcia negocjacji akcesyjnych, po 1991 r. przeprowadziła szereg reform w dziedzinie poszanowania praw i wolności mniejszości narodowych żyjących w Albanii. Obecnie ochrona ta ma charakter w dużej mierze fasadowy. Wprawdzie przyjęto zobowiązania międzynarodowe Konwencji o ochronie praw człowieka i podstawowych wolności oraz ratyfikowano większość międzynarodowych konwencji praw człowieka, jednak kompleksowe przepisy dotyczące mniejszości nie zostały wprowadzone w życie. Objęte prawem mniejszościowym zostały tylko osoby w tzw. strefach mniejszościowych (od 2017 r. tzw. gminach mniejszościowych). Czy jednak zgodnie z ustawą z dnia 13 października 2017 r. rząd w Tiranie będzie poszerzał te uprawnienia na obywateli z poza gmin mniejszościowych, pokaże przyszłość. Prawa do zgromadzeń i stowarzyszania się są na ogół przestrzegane. Mniejszości mają swe przedstawicielstwo w organach samorządowych, nie biorą jednak czynnego udziału w tworzeniu albańskiego prawa. Małe partie mniej- 
szościowe nie mają swych przedstawicieli w parlamencie, gdyż system wyborczy nie daje im takich możliwości. Nieodpowiednie procedury zbierania i przetwarzania danych statystycznych dotyczących liczby i miejsca zamieszkania członków mniejszości narodowych tworzą zafałszowany i niewiarygodny obraz. Mimo to wprowadzane w Albanii reformy, w dużym stopniu monitorowane przez UE i organizacje pozarządowe, obrały dobry kierunek, a prounijne nastawienie społeczeństwa i albańskich władz sprawiają, że braki i luki prawne mogą być szybko uzupełnione.

Słowa kluczowe: prawa mniejszości w Albanii, perspektywa akcesji Albanii do UE, gminy mniejszościowe

\title{
The Rights of National and Ethnic Minorities in Albania in the Post-1991 Period of Political Transformation
}

\begin{abstract}
Making constant progress in the areas of key importance for the start of its accession negotiations, Albania after 1991 has introduced a range of reforms as regards respecting the rights and freedoms of the national minorities living within its territory. Currently, the picture is a mixed one when it comes to their protection and largely based on appearances. Although the international commitments of the Council of Europe's Convention for the Protection of Human Rights and Fundamental Freedoms have been adopted and most international human rights conventions ratified, no comprehensive legislation related to minorities has been put in practice. The minority laws protect only persons in minority zones (since 2017 minority communes). Only time will tell whether the Albanian Government follows the Act of 13 October 2017 extending such rights to embrace citizens from outside of the minority communes. The freedoms of assembly and association are largely respected. Minorities are represented in local government bodies. Yet there are no safeguard to ensure active participation of national minorities in making Albanian law. Small minority parties are not represented in the Parliament as the electoral system offers no such guarantees. Faulty procedures governing the collection and processing of statistical data concerning the number and residence of national minorities result in falsified and unreliable picture as to their volume. However, the reforms carried out in Albania, to a large extent monitored by the EU and NGOs, go in the right direction while the EU-friendly attitude of the Albanian public and authorities alike offer a prospect of speedy implementation of remedies to fill the existing legal gaps and overcome the deficiencies.
\end{abstract}

Keywords: minority rights in Albania, prospects of Albania's EU accession, minority communes 